\title{
SEROLOGICAL RESPONSE TO INTRANASAL ADMINISTRATION OF INACTIVE INFLUENZA VIRUS IN CHILDREN ${ }^{1}$
}

\author{
By J. J. QUILLIGAN, JR., AND THOMAS FRANCIS, JR. \\ (From the Department of Epidemiology and the Virus Laboratory, School of Public Health, \\ and the Department of Pediatrics, Medical School, University of Michigan, Ann Arbor)
}

(Received for publication April 25, 1947)

The published reports on antibody response of human individuals to the inhalation of influenza virus have been most concerned with the effect of active or "attenuated" virus ( 1 to 9 ). In some instances experimental disease was induced to test the efficacy of previous vaccination or to note the effects of inhalation of active virus on the production of antibodies against influenza. Burnet (7) reported that 68 to 80 per cent of a group he studied did not show significant changes in antibody titer when they inhaled an "attenuated" influenza virus preparation. It has been demonstrated (6 to 9) that inhalation of active influenza virus can give a modified form of the disease and result in good antibody responses. It has also been shown (1c, 2 to 5 ) that subcutaneously injected influenza vaccine results in protection against experimentally induced disease. Recently Henle, Henle, Stokes and Maris (10), using serologically determined antibody response as a basis for comparison, concluded that inhalation of active or inactive virus, mostly unconcentrated, was not as effective as subcutaneously injected vaccine.

The present study was conducted to determine the antigenic effect of inactive virus in concentrated form given intranasally, by a single or multiple spray. This effect was compared to that obtained with subcutaneous vaccination.

\section{MATERIAL AND METHODS}

\section{Virus preparation}

The inactive virus preparation was prepared by a commercial biological laboratory from infected allantoic fuid, centrifuged 2 times in a Sharples centrifuge and furnished to the Influenza Commission by W. M. Stanley.

1 This study was aided through the Commission on Influenza, Board for the Investigation and Control of Influenza and Other Epidemic Diseases in the Army, Preventive Medicine Service, Office of the Surgeon General, United States Army.
The virus was inactivated with formalin in a final concentration of $1: 2,000$, and phenyl mercuric nitrate to a concentration of $1: 100,000$ was added. The material originally comprised equal parts of Type $A$ influenza virus ( $1 / 2$ PR8 strain [11] and $1 / 2$ Weiss strain [12]) and the Lee strain (13) of Type B influenza virus. It was estimated to contain $10 \mathrm{mgm}$. of protein per $\mathrm{ml}$. and was received in this laboratory on September 11, 1944. The material was diluted just prior to use on September 30, 1945. When tested serologically on March 13, 1946, a 1:5 dilution in physiological saline gave a hemagglutinating titer of 51,200 and a 1:40 dilution gave a titer of $5,120(14)$.

\section{Subjects}

The children were from 3 cottages of 50 boys each at the Wayne County Training School, Northville, Michigan. The range in age was from 8 to 14 years. Most of the children used were smaller than average in size and of lower than average mental level. The only selection made within the group was the elimination of any children with allergic tendencies.

A total of 80 children was divided into 4 groups. Twenty children from Cottage 1 were used in Group I; 20 children from Cottage 9 constituted Group II ; and 20 children from Cottage 6 made up Group III. The fourth group contained 10 children from Cottage 1 and 10 children from Cottage 9. In the course of the study one child was lost from each group except Group I.

In each cottage there were children who were unvaccinated and who did not receive any control fluid. In Cottage 1 this group consisted of 20 children; in Cottage 9, 20 children; and in Cottage 6, 30 children.

In the vaccinated group there were 11 children who had received a combined influenza virus, Types $\mathrm{A}$ and $\mathrm{B}$, vaccine in January, 1944. Five of them were in Group I; 3 in Group II; and 3 in Group III. None of the children in the control group had been given any previous vaccination against influenza viruses.

\section{Administration of inactive virus preparation}

A 1:5 dilution in physiological salt solution was employed for the intranasal sprays. The atomizer was obtained from the Vaponephrin Company, Upper Darby, Pennsylvania; with 10 lbs. pressure of nitrogen gas it delivered approximately $0.25 \mathrm{ml}$. per 2 minutes. Each individual was sprayed for 1 minute in each nostril. The adapter was washed with antiseptic solution before use 
TABLE I.

Mean antibody titers for the four groups

\begin{tabular}{|c|c|c|c|c|c|c|c|c|c|c|c|c|c|c|c|}
\hline \multirow[t]{2}{*}{ Strain } & \multicolumn{4}{|c|}{$\begin{array}{c}\text { Group I } \\
\text { (5 sprays) } \\
\text { (20 children) }\end{array}$} & \multicolumn{4}{|c|}{$\begin{array}{c}\text { Group II } \\
\text { (1 spray) } \\
\text { (19 children) }\end{array}$} & \multicolumn{4}{|c|}{$\begin{array}{c}\text { Group III } \\
\text { (subcutaneous) } \\
\text { (19 children) }\end{array}$} & \multicolumn{3}{|c|}{$\begin{array}{c}\text { Group IV } \\
\text { (inhalation control) } \\
\text { (19 children) }\end{array}$} \\
\hline & initial & 2 wks. & $\begin{array}{c}\text { fold } \\
\text { increase }\end{array}$ & 5 mos. & initial & 2 wks. & $\underset{\text { increase }}{\text { fold }}$ & 5 mos. & initial & 2 wks. & $\underset{\text { increase }}{\text { fold }}$ & 5 mos. & initial & 2 wks. & 5 mos. \\
\hline $\begin{array}{l}\text { PR8 } \\
\text { Weiss } \\
\text { Lee }\end{array}$ & $\begin{array}{r}224 \\
192 \\
58\end{array}$ & $\begin{array}{l}745 \\
588 \\
691\end{array}$ & $\begin{array}{r}3 \times \\
3 \times \\
12 \times\end{array}$ & $\begin{array}{l}563 \\
499 \\
435\end{array}$ & $\begin{array}{r}148 \\
218 \\
40\end{array}$ & $\begin{array}{l}443 \\
538 \\
294\end{array}$ & $\begin{array}{l}3 \times \\
2 \times \\
7 \times\end{array}$ & $\begin{array}{l}297 \\
148 \\
430\end{array}$ & $\begin{array}{r}310 \\
269 \\
84\end{array}$ & $\begin{array}{r}1363 \\
942 \\
1935\end{array}$ & $\begin{array}{r}4 \times \\
3 \times \\
23 \times\end{array}$ & $\begin{array}{l}701 \\
499 \\
891\end{array}$ & $\begin{array}{r}134 \\
196 \\
32\end{array}$ & $\begin{array}{r}141 \\
196 \\
32\end{array}$ & $\begin{array}{c}128 \\
196 \\
99.8\end{array}$ \\
\hline
\end{tabular}

by another subject. Precautions were taken to minimize the inhalation of the sprayed material by any other than the selected subjects. Each child was brought individually into the spray room which was located on the upper floor of Cottage 1. The room was unused except for spraying throughout the study period.

For subcutaneous administration $1.0 \mathrm{ml}$. of a $1: 40$ dilution of the inactive virus was given in the left arm. A clean sterile needle was used for each individual.

Group I received intranasal inhalations of the $1: 5$ dilution of inactive virus on October $1,2,3,4$, and 5 , 1945. Group II received 1 intranasal inhalation of the 1:5 dilution on October 2, 1945. Group III was given $1.0 \mathrm{ml}$. of the $1: 40$ dilution subcutaneously on October 3, 1945. Group IV received 1 intranasal inhalation of sterile normal allantoic fluid on October 1, 1945. These last inhalations were given in a cottage well removed from that in which the spraying of the inactive virus preparation was carried out.

Oral temperatures were taken on October 1, 2, 3, 4, and 5, 1945, in Groups I, II and IV. Signs and symptoms of reactions were recorded daily in all groups. Group III had oral temperatures recorded on October 3, 4, and 5; on the latter 2 days the site of subcutaneous inoculation was examined and the children observed for systemic signs and symptoms.

\section{Serological studies}

Blood was drawn from each individual immediately before vaccination, 2 weeks after vaccination, and 5 months after vaccination. The second blood specimens were obtained from those receiving 5 intranasal inhalations 2 weeks after the third dose. Agglutination-inhibition titrations of chicken red blood cells were done according to Salk's modification (14) of Hirst's method (15). The sera from a given individual were all tested at the same time. Agglutination-inhibition was measured against the PR8 and Weiss strains of Type $A$ virus, and the Lee strain of Type $B$ virus. The same virus preparations were used for all tests. The chicken red blood cells were taken from animals whose cells had been checked repeatedly and found to be satisfactory.

\section{RESULTS}

\section{Response to influenza virus, Type $A$}

The sera from the 4 study groups exhibited varying degrees of agglutination-inhibition with the PR8 strain of Type A influenza virus. A comparison of the serological findings in the 3 vaccinated groups and the control group is presented in Figures 1, 2 and 3 . The modified arithmetic means are summarized for all groups in Table I. ${ }^{2}$

The 20 individuals in Group $I$, who received 5 intranasal inhalations, had an initial mean titer against the PR8 strain of $224 ; 2$ weeks later this rose to a mean of 745 and represented an increase of 3.3 times the initial value. Five months later it had dropped to 563 . The distribution of these sera indicates that 2 weeks after vaccination, 12 had a 4-fold or greater increase in titer against

TABLE II

Comparison of antibody level before and 2 weeks after administration of inactive virus

\begin{tabular}{l|c|c|c|c|c|c}
\hline \hline Strain & $\begin{array}{c}\text { Group I } \\
(20 \text { children })\end{array}$ & $\begin{array}{c}\text { Group II } \\
(19 \text { children })\end{array}$ & $\begin{array}{c}\text { Group III } \\
(19 \text { children })\end{array}$ \\
\cline { 2 - 7 } & $\begin{array}{c}2 \times \text { or } \\
\text { less }\end{array}$ & $\begin{array}{c}4 \times \text { or } \\
\text { more }\end{array}$ & $\begin{array}{c}2 \times \text { or } \\
\text { less }\end{array}$ & $\begin{array}{c}4 \times \text { or } \\
\text { more }\end{array}$ & $\begin{array}{c}2 \times \text { or } \\
\text { less }\end{array}$ & $\begin{array}{c}4 \times \text { mor } \\
\text { more }\end{array}$ \\
PR8 & $8^{*}$ & $12 \dagger$ & 12 & 7 & 5 & 14 \\
Weiss & 11 & 9 & 14 & 5 & 10 & 9 \\
Lee & 4 & 16 & 4 & 15 & 1 & 18 \\
\hline
\end{tabular}

* Number of individuals with 2 -fold or less increase in titers.

$\dagger$ Number of individuals with 4-fold or greater increase in titers.

2 All titers are expressed as the reciprocal of the highest final dilution of serum giving inhibition of agglutination. The mean titration figures for each group of sera were arrived at in the following manner. The numbers $1,2,3$, etc., were assigned to the dilutions of sera (e.g., $1=<32 ; 2=32 ; 3=64$; et seq.). The number of individuals having a certain titer was then multiplied by the number assigned to that titer (e.g., $32=2$; therefore $2 \times$ $3=6$ ). The totals for each designated number were then added and this result divided by the number of sera in the group. This was then reconverted to the titer it represented and any fraction was multipled by the titer the whole number represented (e.g., 2.35 is equivalent to $32+$ $[32 \times 0.35]$ ). 
the PR8 strain, and 8 had a 2 -fold increase or less, when compared to the titers before the virus preparation was administered (Table II).

The sera from the 19 children in Group II when measured against the PR8 strain gave an initial mean titer of 148 with a rise to 443 , an increase of approximately 3 times the initial titer, 2 weeks after the single inhaled dose. As indicated in Table II, 7 sera had 4-fold or greater increases in titer and 12 had 2 -fold or less. The mean value 5 months later had dropped to 297 .

When titrated with the PR8 strain, the sera of the 19 subcutaneously vaccinated children in Group III had an initial mean titer of $310 ; 2$ weeks after vaccination, 1,363; and 5 months later, 701. Of the 19 sera tested, 14 had a 4-fold or greater increase in titer 2 weeks after vaccination, and 5 had a 2 -fold increase or less. The 5
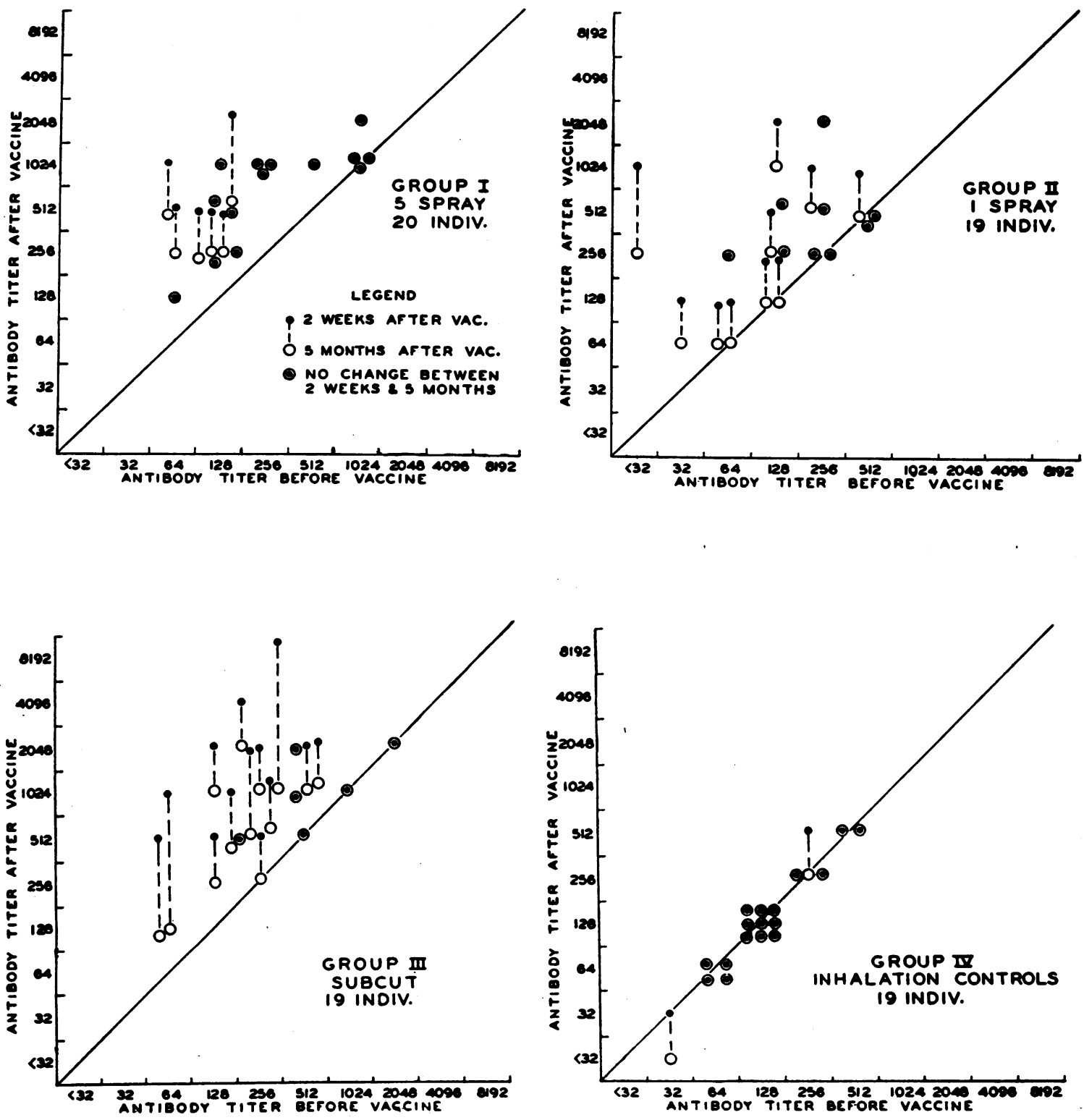

Fig. 1. Change in Antibody Titer Measured against the PR8 Strain 2 Weeks and 5 Months after VacCINE WAS AdMinistered 

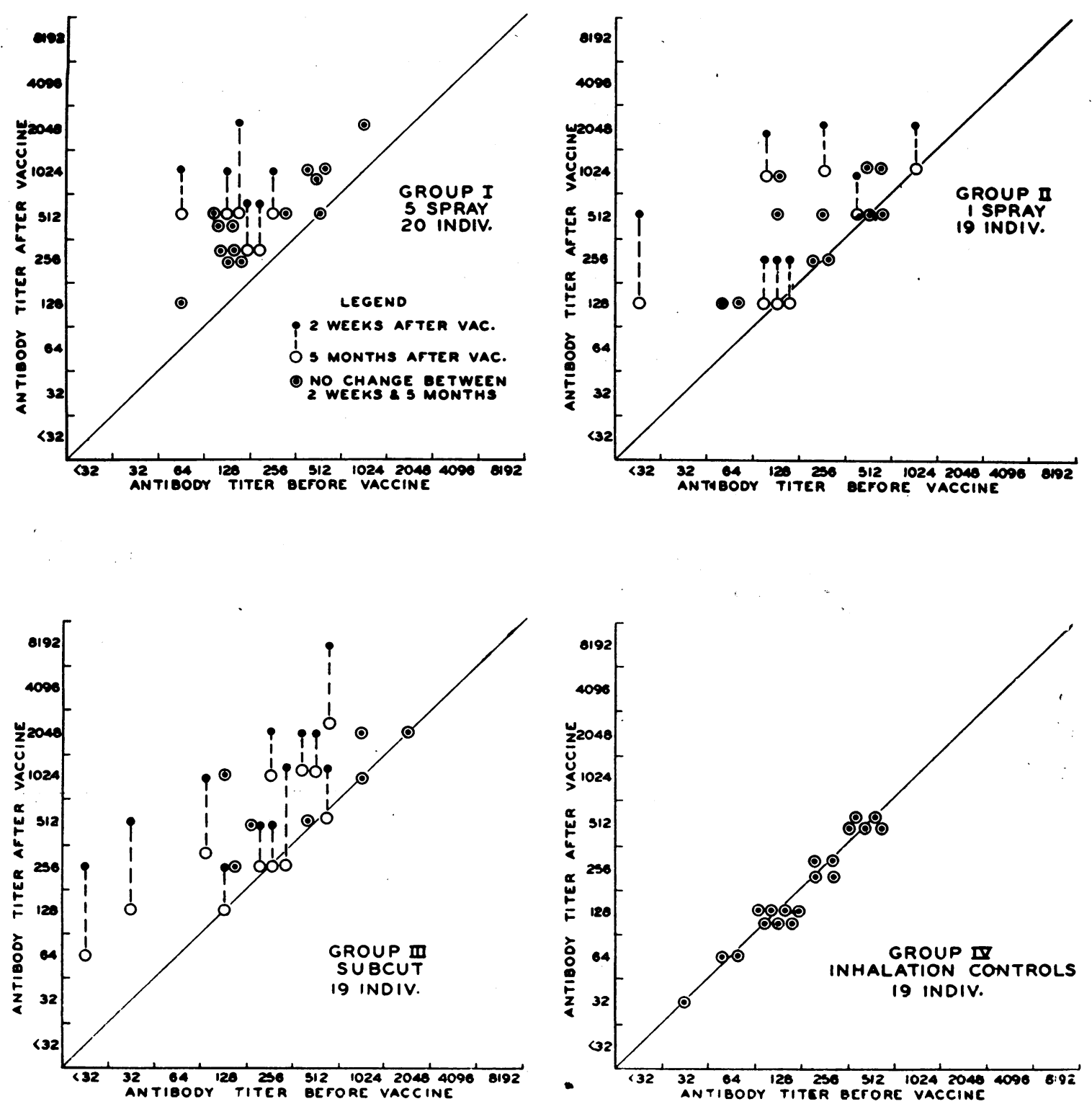

Fig. 2. Change in Antibody Titer Measured against the Weiss Strain 2 Weeks and 5 Months after VacCiñe Was Administered

who showed the increases of 2 -fold or less all had initial titers of 256 or higher. Five months after vaccination the sera showed a sharp drop with 9 falling 2 -fold, 1 falling 4 -fold, 2 falling 8-fold; and 6 had no change in titer (Figure 1).

The subjects who received the single inhalation of normal allantoic fluid in Group IV showed no appreciable change in titers when measured against the PR8 strain of influenza virus. However, it is worth noting that the sera of 2 individuals showing changes in titer were decreases against the PR8 strain; and later it will be shown that the control group when measured against the Lee strain of Type B virus showed marked rises in titer.

The serological responses of the 4 groups were similar to the above patterns when measured against the Weiss strain of Type $A$ influenza virus (Figure 2). The differences are most noticeable in Group III, where the PR8 titers were 
greater than the Weiss titers, and 5 months after vaccination less of a drop occurred with the former. The difficulty in interpreting antibody response to various strains of influenza virus has been commented on by others. Burnet and Lush (16) have assumed that any measurement of specific antibody will always include some non-specific antibody. This was shown to be true by Hirst (17). More recent evidence lends weight to the supposition that the agglutination-inhibition mechanism is a complex one and that too exact interpretation of results may lead to er- roneus conclusions (18). In any event, a study of Table I and the spot charts does show, a consistent picture of high initial antibody titers to both strains of Type A virus. Whether this represents previous specific experience on the part of the subjects with these Type A virus strains or is related to peculiarities of the PR8 and Weiss preparations, to non-specific characteristics of the sera used in the tests, or to combinations of these influences, one cannot surely state. Certainly, in view of the Type A epidemic in 1943 (12), the
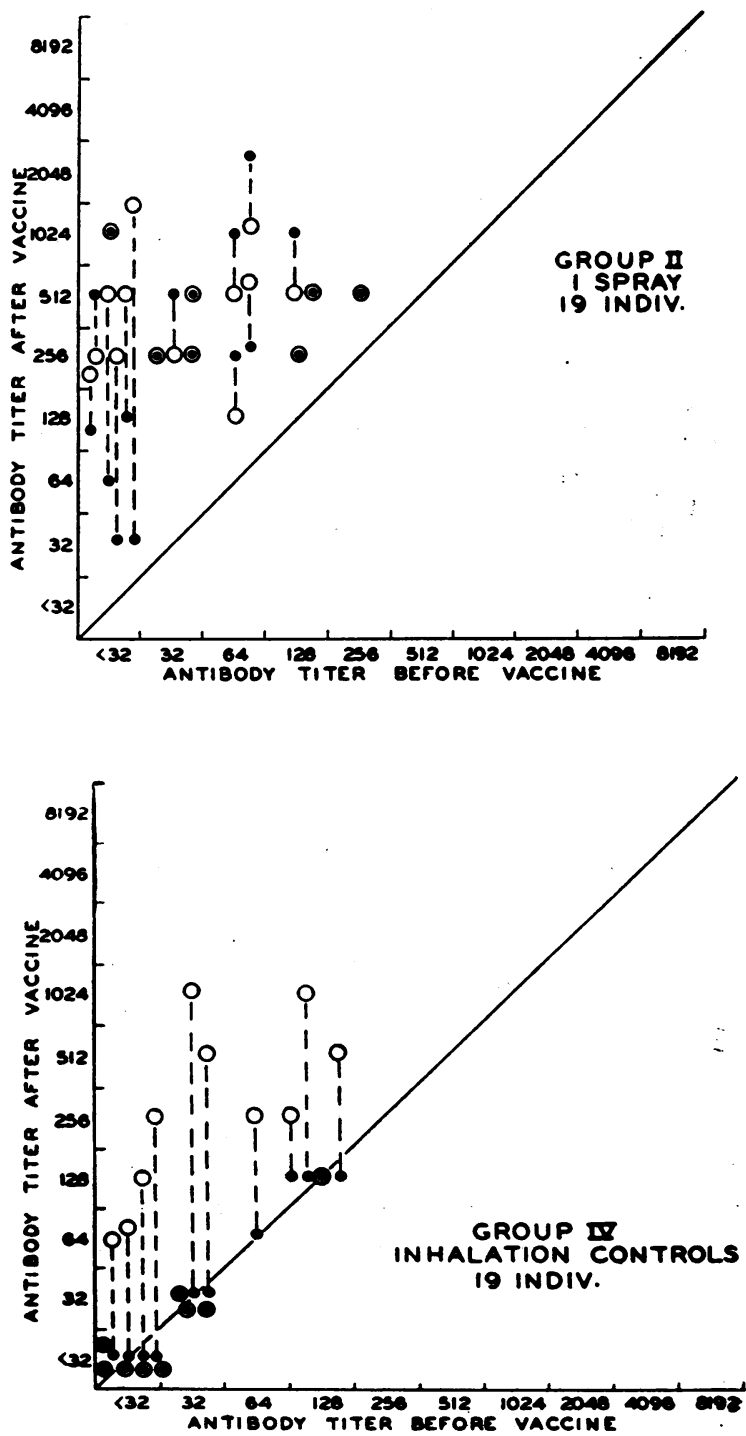

Fig. 3. Change in Antibody Titer Measured against the Lee Strain 2 Weeks and 5 Months after VacCINE WAS AdMinistered 
possibility of previous contact with A strains is a strong one.

\section{Responses to the Lee strain of Type $B$ influenza virus}

When the 4 groups of sera were tested against the Lee strain of Type B virus, a marked difference in antibody response, when compared with A, was apparent (Figure 3 ). The mean values listed in Table I show much lower initial titers for all 3 groups against the $B$ strain. Possibly this is an indication of less experience with the Type B strains, resulting in a fuller response to the antigenic stimulus.

In Group $I$, after 5 daily sprays, the initial mean value was 58 ; this rose to 6912 weeks after vaccination, representing an increase of 12 times the initial titer. Five months later the mean was 435 . Table II lists the distribution when the sera taken 2 weeks after vaccination were compared with the initial values. Sixteen of the 20 in the group had a 4-fold or greater increase in titer and 4 showed a 2 -fold increase. The sera taken 5 months after vaccination did not show the same drop in titers that was noted with the A strains. Although 11 sera did have decreases in titer, 3 sera had 2 -fold rises in titer. In the interval between the bloods drawn 2 weeks and 5 months after vaccination, an epidemic of influenza $\mathrm{B}$ was noted. This will be discussed in more detail later.

The Group II sera, from the individuals receiving the single spray of inactive virus preparation, had similar responses when measured against the Lee strain of Type $B$ influenza virus. The mean titers for the 3 sets of sera in this group were: initial, $40 ; 2$ weeks after vaccination, 294; 5 months after vaccination, 430 . The sera taken 2 weeks after vaccination, when compared to the pre-vaccination sera, showed 15 with a 4 -fold or greater increase in titer and 4 with a 2 -fold increase. A comparison with the sera taken 5 months later gave 6 with a drop in titer and an equal number with 2 -fold or greater increase in titer. The spot charts in Figure 3 show this change. The same situation existed as in Group $I$; namely, an epidemic of Type B influenza that involved enough members of this group to cause a definite increase in a number of the agglutina- tion-inhibition titers against the Lee strain of Type $B$ influenza virus.

Group III, after the subcutaneous dose, showed the most striking responses against the Lee strain. The mean titers were: initial, 84; 2 weeks after vaccination, 1,$935 ; 5$ months after vaccination, 891. The increase 2 weeks after vaccination was approximately 23 times the initial mean titer and 5 months later it was 10 times the initial titer. The distribution of the 19 sera in this group is shown in Table II and indicates that 18 of the bloods taken 2 weeks after vaccination exhibited 4-fold or greater responses and one had a 2 -fold increase when compared to the pre-vaccination levels. Of the sera taken 5 months after vaccination 9 had 2 -fold decreases in titer and 6 had 4-fold or greater decreases in titer. In this same set of sera there were 3 with no change in titer and 1 serum with a 2 -fold increase in titer.

Group IV, the sera from the inhalation controls, when titrated against the Lee strain of Type $B$ influenza virus, showed no change between the initial titers and those of 2 weeks later. It has been previously stated that an outbreak of Type $B$ influenza occurred in the institution in the interval between the 2 -week bleedings and the 5-month bleedings. During this period the members of the various groups were under close clinical observation. When the 19 sera taken 5 months after vaccination were titrated against the Lee strain, 10 had increases in titer ranging from 2 -fold to 32 -fold (Figure 3 ). All but 1 of the 10 were 4 -fold or greater increases in titer.

The levels of antibody which will be attained by human individuals in response to influenza vaccination may vary widely. Results of small groups of subjects cannot be too freely evaluated. The above data can only indicate broad, general trends of antibody response. Even the fact that the response to the strain of Type $B$ virus was numerically better than $A$ must be accepted with reservation. Other studies have indicated that the Lee strain, measured in terms of protection against natural and experimental disease, induces a stauncher degree of protection than certain A strains of influenza virus $(4,5,19)$. The low initial titers to the Lee strain were associated with more striking increases in titer 2 weeks after vaccination and, conversely, the higher original 
titers to the A strains minimized the increments in titer after vaccination. The figures listed in Table $I$ indicate that the mean-fold increase was greater against the Lee strain than either PR8 or Weiss. However, the mean titers of the 2week bleedings were not so sharply differentiated except in Group III. If generalizations are to be made one can point out that the mean-fold increase in titer to $B$ was better than that to $A$ although the differences between titers were not consistent; that subcutaneous vaccination appeared to be more effective than intranasal although rather uniform responses were obtained with the latter. It is of interest to note that the group receiving the 5 sprays had a total of 1.25 $\mathrm{ml}$. of a $1: 5$ dilution of vaccine whereas the subcutaneous group received $1 \mathrm{ml}$. of the $1: 40$ dilution of vaccine, strongly suggesting that subcutaneously injected vaccine was more efficiently utilized. These studies with concentrated inactive material support the impression obtained from the results of Henle et al (10).

The subcutaneous vaccinations resulted in excellent antibody production against the Lee strain but in a lesser response to the A strains. $\mathrm{Nu}$ merically the antibody titers in the subcutaneous group were higher than in previous experiments with adults $(3,5,19)$. Proof of whether this represents chance or that children in this age group do respond better and more consistently, would require studies with large groups of children.

As already mentioned, some of the subjects in the vaccinated groups had received a combined $A$ and B influenza virus vaccine in January, 1944. Their initial anti-A titers were not significantly different from the remainder of the groups so they could not be considered the cause of the higher initial titers to Type A. For the Lee strain the initial titers of those who received vaccine in 1944 were 2 times greater than the rest of the group. However, the number within each group was small enough to show only a minimal influence on the height of the mean initial titer for each study group.

\section{Reactions}

The reactions to the intranasal inhalation of the combined inactivated viruses were minimal.
In the group who received the 5 daily sprays, 6 children had oral temperatures between $100.0^{\circ}$ and $100.8^{\circ} \mathrm{F}$. on the third day. Two children, after the first spray, complained of a slight sensation of fullness in the head. Two children on the fourth day had temperatures between $100.0^{\circ}$ and $100.2^{\circ} \mathrm{F}$. The single inhalation group and the control inhalation group had no reactions. Twelve of the children in Group III complained of local reactions 24 hours after the subcutaneous inoculation. Of the 12 children, 3 had slight erythema; 7 had tenderness, heat and erythema; and 2 had tenderness, heat, redness and swelling at the site of injection with axillary nodes palpable on the affected side. There were 3 children in this group with temperatures between $100.4^{\circ}$ and $100.8^{\circ} \mathrm{F}$; and 1 child, who had a severe local reaction, complained of dizziness and slight headache.

\section{CLINICAL OBSERVATIONS}

From December, 1945, through January, 1946

Following the vaccinations done in October, 1945, periodic observations were made to determine influenza virus infection in the institution. On November 10,1945, Type B influenza virus was isolated in Michigan (19) and on December 13, 1945, several children at the Training School reported to the sick ward with an acute illness characterized by fever, chills, prostration, headache and sore throat. The number of cases throughout the school reached a peak on December 18 and fell off gradually until only occasional cases were occurring from December 18 through January 30, 1946. From throat washings of 2 of the children admitted to the sick ward on December 18, Type B influenza virus was recovered. The children from the 3 cottages that housed the 4 groups were followed closely during the interval of time covering the outbreak. Eight of the 58 children in the 3 vaccinated groups developed clinical evidence of disease. Twentynine of the 89 unvaccinated children from the 3 cottages developed clinical evidence of influenza. This includes 4 children from the inhalation control group.

From $69^{8}$ cases the clinical findings in order of

${ }^{8}$ This number of individuals includes children from other cottages than those in the study groups. 
their frequency were: sore throat, temperature elevation, rhinorrhea, headache, chills and cough. Less prominent findings were excessive lacrimation (frequently associated with the complaint of burning eyes), malaise and sneezing. The sick children showed few abnormal physical findings. Prostration and lethargy during the first 12 to 24 hours was common. Moderate injection of the pharynx and a thin watery discharge appearing on the second day and rarely becoming purulent was often noted. Prompt recovery was the rule. Two children with perforated ear drums and associated chronic otitis media developed purulent aural discharges following the primary infection. They were the only complicated cases.

The total number of cases involving the children in the 4 study groups was 12: 4 of these were from the control group; 4 were from the group receiving the single inhalation; 3 were from the group receiving the 5 daily inhalations; and 1 was from the subcutaneously vaccinated group. However, when the sera from the above groups were tested 5 months after receiving the inactive virus preparation there were some individuals who showed rises in titer above the 2 -week level without any clinical evidence of disease; other children who did have clinical evidence of influenza-like disease showed no rise in antibody titer in convalescence or again 5 months after the vaccination study was started. This is most noticeable in Group IV, the 19 inhalation controls, where the antibody response to infection was not masked by the effect of the inactive virus preparation. Only 1 of the 4 subjects in this group who developed clinical signs of influenzalike disease had a rise in titer against the Lee strain. The other 3 children had no rise in titer and in every determination the titers of these 3 were 32 or under when measured against the Lee strain." There were no changes in the titers of the A strains in these sera. In this same group of 19 children the titers of the sera taken 5 months after vaccination showed 10 individuals with rises in titer, one of them being the child described above. The other 9 had no record of illness. The phenomenon of sub-clinical infection, as exemplified by the 9 individuals without evidence of

4 These sera were tested against a strain of Type B virus isolated during the epidemic. The results showed no rise in antibodies against the current strain. infection and yet having rises in antibody titer in the sera taken 5 months after vaccination, is well recognized. However, the 3 individuals with evidence of disease but without rises in agglutinationinhibition antibodies are more difficult to evaluate. The use of antibody response, as currently measured, is not feasible for the diagnosis of influenza in vaccinated populations; with such a premise, then, clinical findings must be accepted for unvaccinated subjects as well. There did not seem to be any correlation between initial titer and sub-clinical infection (20).

It can be seen from Figure 3 that some rises in titer occurred during the same interval in the other groups. The subcutaneously injected group had 1 subject with a 2 -fold rise in titer who showed no evidence of disease and 1 subject, whose titer was 2048, did show clinical evidence of influenza. The 5-spray group had 3 children with 2 -fold rises in titer; only 1 showed evidence of disease and 2 others in this group with influenza did not have rises in titer; however, their titers were 256 and 1,024. The single inhalation group had 6 subjects with rises in titer; 2 with 2 -fold rise; 1 with 4 -fold rise; 2 with 8 -fold rise; and 1 with 32 -fold rise. Of the 6 there were 4 with clinical evidence of disease. Such figures further indicate the difficulty in interpreting clinical disease in terms of antibody response when vaccinations are carried out. Obviously, the use of the serological test is of little help. The possibility that the rises in titer seen in sera 5 months after vaccination were a continuation of the effect of vaccination is quite remote. There were no rises in titer against the A strains. Also, enough of the children who became ill had additional sera taken during the period between the 2-week and 5-month bleedings to indicate that there was a fairly consistent drop in antibody titer associated with the vaccinations. In most instances the titers 2 weeks after illness were higher and then fell to lower levels 5 months after the inactive virus preparation was administered. No significant evaluation of the effects of administration of the virus materials upon the incidence of infection with influenza virus can be made from these observations nor was the study intended for that purpose. Nevertheless, a difference in the frequency of respiratory illness among the vaccinated and unvaccinated groups was seen. 
The presence of clinically undetected influenza B infection was demonstrated by the surprisingly large number of antibody rises to Type $B$ virus in sera obtained 5 months after vaccination while A titers were continuing to fall.

\section{SUM MARY}

The data reported here indicate that a single intranasal inhalation of an inactivated influenza virus preparation resulted in good antibody responses and that the use of 5 daily sprays gave slightly higher levels of antibody. A comparison of the effect of the 2 different doses of intranasal vaccine on the sera taken 5 months after vaccination suggests that the larger dose gave a more persistent elevation in antibody titer.

The vaccine given intranasally on 5 successive days contained approximately 8 times as much inactive virus preparation as the subcutaneous material. However, a comparison of the antibody responses indicates that subcutaneously administered vaccine gives higher and more persistent levels with smaller doses. Clinical observations were made during an epidemic of influenza $B$ in the institution.

\section{ACKNOWLEDGMENTS}

The authors wish to express their gratitude for the pleasant, cooperative efforts of Mrs. B. Brannon, Doctor R. H. Haskell, and the staff of the Wayne County Training School, and also to Miss Elva Minuse and Miss Hilda Kurtz of the Virus Laboratory.

\section{BIBLIOGRAPHY}

1. a. Smorodintseff, A. A., Tushinsky, M. D., Drobyshevskaya, A. I., Korovin, A .A., and Osetroff, A. I., Investigation on volunteers infected with the influenza virus. - Am. J. M. Sc., 1938, 194, 159.

b. Burnet, F. M., and Foley, M., The results of intranasal inoculation of modified and unmodified influenza virus strains in human volunteers. M. J. Australia, 1940, 2, 655.

c. Henle, W., Henle, G., and Stokes, J., Jr., Demonstration of the efficacy of vaccination against influenza type $A$ by experimental infection of human beings. J. Immunol., 1943, 46, 163.

d. Francis, T., Jr., Intranasal inoculation of human inviduals with virus of epidemic influenza. Proc. Soc. Exp. Biol. \& Med., 1940, 43, 337.

2. Francis, T., Jr., Salk, J. E., Pearson, H. E., and Brown, P. N., Protective effect of vaccination against induced influenza A. Preliminary Report, Proc. Soc. Exper. Biol. \& Med., 1944, 55, 104.

3. Francis, T., Jr., Salk, J. E., Pearson, H. E., and Brown, P. N., Protective effect of vaccination against induced influenza A. J. Clin. Invest., 1945, 24, 536.

4. Salk, J. E., Pearson, H. E., Brown, P. N., and Francis, T., Jr., Protective effect of vaccination against induced influenza B. Preliminary Report. Proc. Soc. Exper. Biol. \& Med., 1944, 55, 106.

5. Salk, J. E., Pearson, H. E., Brown, P. N., and Francis, T., Jr., Protective effect of vaccination against induced influenza B. J. Clin. Invest., 1945, 24, 547.

6. Burnet, F. M., Influenza virus B. II. Immunization of human volunteers with living attenuated virus. M. J. Australia, 1942, 1, 673.

7. Burnet, F. M., Immunization against influenza with living attenuated virus. M. J. Australia, 1943, 1, 385.

8. Mawson, J., and Swan, C., Intranasal vaccination of humans with living attenuated influenza virus strains. M. J. Australia, 1943, 1, 394.

9. Francis, T., Jr., Pearson, H. E., Salk, J. E., and Brown, P. N., Immunity in subjects artificially infected with influenza virus, Type B. Amer. J. Pub. Health, 1944, 34, 317.

10. Henle, W., Henle, G., Stokes, J., Jr., and Maris, E. P., Experimental exposure of human subjects to viruses of influenza. J. Immunol., 1946, 52, 145.

11. Francis, T., Jr., Transmission of influenza by a filtrable virus. Science, 1934, 80, 457.

12. Salk, J. E., Menke, W. J., and Francis, T., Jr., Identification of influenza virus Type $A$ in a current outbreak of respiratory disease, J. A. M. A., 1944, 124, 93.

13. Francis, T., Jr., A new type of virus from epidemic influenza. Science, 1940, 92, 405.

14. Salk, J. E., A simplified procedure for titrating hemagglutinating capacity of influenza virus and the corresponding antibody. J. Immunol., 1944, 49, 87.

15. Hirst, G. K., The quantitative determination of influenza virus and antibodies by means of red cell agglutination. J. Exper. Med., 1942, 75, 49.

16. Burnet, F. M., and Lush, D., Influenza virus strains isolated from Melbourne 1939 epidemic. Australian J. Exper. Biol. and M. Sc., 1940, 18, 49.

17. Hirst, G. K., Studies of antigenic differences among strains of influenza $A$ by means of red cell agglutination. J. Exper. Med., 1943, 78, 407.

18. Francis, T., Jr., Dissociation of hemagglutinating and antibody measuring capacities of influenza virus. J. Exper. Med., 1947, 85, 1.

19. Francis, T., Jr., Salk, J. E., and Brace, W. M., The protective effect of vaccination against epidemic influenza B. J. A. M. A., 1946, 131, 275.

20. Burnet, F. M., Cade, J. F. J., and Lush, D., Serological response to influenza virus infection during epidemic, with particular reference to sub-clinical infection. M. J. Australia, 1940, 1, 397.

21. Magill, T. P., and Sugg, J. Y., The significance of antigenic difference among strains of the $A$ group of influenza viruses. J. Exper. Med., 1944, 80, 1. 